\author{
Adam Szelag \\ Politechnika Warszawska \\ Marcin Steczek \\ Politechnika Łódzka
}

\title{
Wpływ parametrów filtru wejściowego i sterowania PWM na impedancje wejściową układu napędowego z falownikiem napięcia
}

\begin{abstract}
Impedancja wejściowa elektrycznego pojazdu trakcyjnego jest parametrem decydujacym o stopniu przenoszenia się zakłóceń elektrycznych z sieci jezdnej do obwodu powrotnego. W celu ograniczenia wplywu tych zaktóceń na obwody torowe, parametr ten powinien być utrzymany na odpowiednio wysokim poziomie. Najlepsza metoda oszacowania impedancji wejściowej pojazdu na etapie projektowania jest wykorzystanie symulacji komputerowych. W artykule przedstawiono wyniki wyznaczania impedancji wejściowej falownikowego ukladu napędowego z zastosowaniem metody symulacji komputerowej. dla przypadku bez modulacji napięcia wyjściowego jak również z modulacja PWM. Wykazano, że istniejq warunki, w których (dla określonych parametrów filtru wejściowego) impedancja pojazdu trakcyjnego nie jest statq wartościa, a w istotny sposób zależy od punktu pracy przetwornicy.
\end{abstract}

\section{Wprowadzenie}

W ostatnich latach znakomita większość pojazdów trakcyjnych wprowadzanych do ruchu na polskich szlakach kolejowych są to pojazdy wyposażone w nowoczesne przetwornice półprzewodnikowe. Zastosowanie tego typu urządzeń pozwala na:

- ograniczenie strat przy rozruchu pojazdu trakcyjnego,

- zastosowanie silnika asynchronicznego do napędu pojazdu,

- eksploatacje jednego pojazdu przy współpracy $\mathrm{z}$ wieloma systemami zasilania trakcji elektrycznej (pojazdy wielosystemowe),

- zastosowanie hamowania odzyskowego, co umożliwia zmniejszenie zużycia energii,

- płynne sterowanie napędem.

Dotyczy to zarówno lokomotyw, jaki i elektrycznych zespołów trakcyjnych (EZT). Przez lata eksploatacji pojazdów z silnikami szeregowymi i rozruchem rezystorowym infrastruktura polskich szlaków została przystosowana do obsługi tego typu pojazdów. $\mathrm{Z}$ tego powodu pojawienie się nowoczesnych technologii wymaga dokładnych badań i analizy na tle kompatybilności pomiędzy pojazdem a infrastrukturą kolejową, na którą składają się przede wszystkim układ zasilania i układ sterowania ruchem kolejowym. W celu ograniczenia kosztów badań, najprostszym rozwiązaniem jest zastosowanie narzędzi symulacyjnych $\mathrm{z}$ zaimplementowanymi modelami analizowanych układów. Modele powinny być odpowiednio dobrane w zależności od charakteru i celu badań. Zagadnieniom modelowania i symulacji obwodu: podstacja trakcyjna-sieć zasilająca- pojazd poświęcono szereg $\operatorname{prac}[2,3,4,5,6,7,8,9,10]$

\section{Impedancja wejściowa pojazdu trakcyjnego}

Kompatybilność w trakcji elektrycznej jest bardzo szerokim zagadnieniem obejmującym wiele dziedzin wiedzy i oddziaływania miedzy wieloma podsystemami trakcji. Impedancja wejściowa pojazdu trakcyjnego jest problemem $\mathrm{z}$ zakresu kompatybilności pomiędzy pojazdem trakcyjnym, systemem zasilania trakcji elektrycznej i systemem sterowania ruchem kolejowym. Można wyróżnić wiele źródeł zakłóceń dla systemu sterowania ruchem kolejowym. Do najbardziej istotnych można zaliczyć

- harmoniczne napięcia od podstacji trakcyjnej W stanie normalnym harmoniczne charakterystyczne,

- harmoniczne napięcia od podstacji trakcyjnej w stanie awarii - harmoniczne niecharakterystyczne,

- harmoniczne prądu w obwodzie powrotnym od pojazdów trakcyjnych,

Wpływ wyżej wymienionych zakłóceń ogranicza się przez stosowanie filtrów rezonansowych na podstacjach i wprowadzenie ograniczeń widma prądu generowanego przez pojazd trakcyjny w pasmach częstotliwości wykorzystywanych przez obwody torowe. Dopuszczalne parametry zakłóceń dla obwodów torowych określono w pracy [1] Jednakże w napięciu zasilającym mogą się pojawić zakłócenia 
trudne do przewidzenia, których przyczyną mogą być zarówno stany awaryjne zespołów prostownikowych jak również oddziaływanie na siebie kilku pojazdów trakcyjnych wyposażonych $\mathrm{w}$ przetwornice statyczne, operujących na jednym odcinku zasilania. Szczególnie w drugim przypadku poziom i zakres zakłóceń jest bardzo trudny do określenia ze względu na losowy charakter zjawiska. Zakłócenia te, gdy przeniosą się do obwodu powrotnego mogą zakłócać prace obwodów torowych. Parametrem decydującym o stopniu przenoszenia się zakłóceń z sieci zasilającej do obwodu powrotnego jest impedancja wejściowa pojazdów trakcyjnych operujących na danym odcinku zasilania. Np. w normie PN-EN 50388 dla $50 \mathrm{~Hz}$ podawana jest wymagana wartość impedancji wejściowej powyżej $2 \Omega$. Jedną z metod ograniczania tego typu zakłóceń może być np. monitorowanie widma harmonicznych i na jego podstawie odpowiednie sterowanie przetwornicą w celu uniknięcia przekroczenia dopuszczalnego poziomu harmonicznych $\mathrm{w}$ określonych przedziałach częstotliwości. Metoda ta wymaga opracowania systemu współpracy układu monitorującego z układem sterowania napędem, co przy konieczności zachowania właściwości trakcyjnych pojazdu jest poważnym wyzwaniem. Prostszą metoda jest ustalenie minimalnej wymaganej impedancji wejściowej pojedynczego pojazdu w funkcji częstotliwości i utrzymywanie jej na odpowiednim poziomie. We wcześniejszych pracach autorów [8,9] wykazano, że istnieją warunki, w których impedancja wejściowa pojazdu wyposażonego $\mathrm{w}$ przetwornice statyczne może ulegać zmianie w zależności od punktu pracy. W niniejszym artykule przedstawiono wyniki badań dotyczących symulacyjnego wyznaczania impedancji wejściowej pojazdu $\mathrm{z}$ wykorzystaniem uproszczonego modelu napędu składającego się z filtru wejściowego, falownika i silnika asynchronicznego.

\section{Modele symulacyjne}

Do celów pracy opracowano $\mathrm{w}$ programie symulacyjnym dwa modele obwodu głównego pojazdu trakcyjnego wyposażonego w falownikowy układ napędowy (Rys. 1):

MODEL 1 - w modelu tym nie występuje modulacja napięcia wyjściowego. Zmiana punktu pracy przetwornicy następuje jedynie przez zmianę częstotliwości fali nośnej,

MODEL 2 - w modelu tym zastosowano modulacje PWM. Pozwala to na wprowadzenie dowolnej częstotliwości fali nośnej a jednocześnie na zmianę głębokości i częstotliwości modulacji.

W obu przypadkach zastosowano następujące uproszczenia:

- elementy półprzewodnikowe przetwornicy zastapiono idealnymi łącznikami. Pozawala to na skrócenie czasu obliczeń bez wpływu na dokładność uzyskanych wyników,

- silnik asynchroniczny zamodelowano jako symetryczne obciążenie RL z pominięciem gałęzi magnesującej. Znaczna impedancja gałęzi magnesującej połączona równolegle ze stosunkowo niską impedancja obwodu wirnika, ma znikomy wpływ na wyniki wyznaczania impedancji układu, natomiast ze względu na duża wartość indukcyjności powoduje znaczne wydłużenie czasu obliczeń,

- sterowanie falownikiem realizowane jest w otwartej pętli sprzężenia zwrotnego. Parametry sterowania są ustawiane na początku symulacji i ich wartość jest stała w trakcie jej trwania,

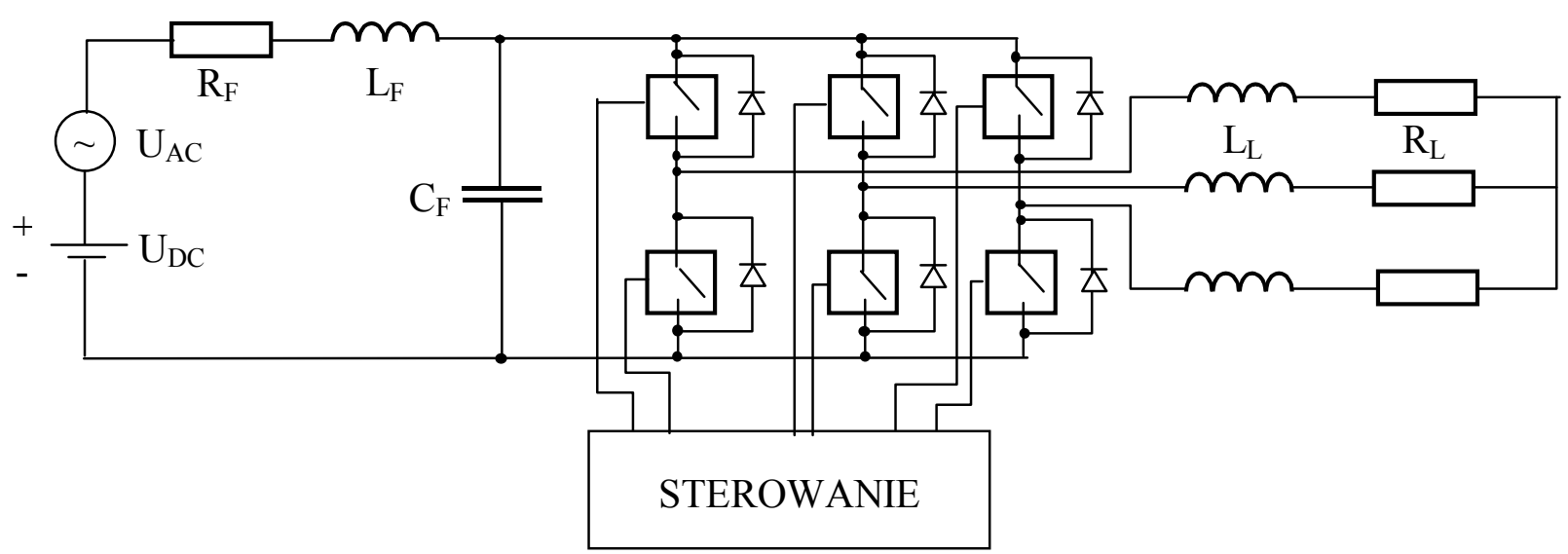

Rys. 1 Schemat modelu symulacyjnego. $\mathrm{R}_{\mathrm{F}}$ - rezystancja filtru, $\mathrm{L}_{\mathrm{F}}$ - indukcyjność filtru, $C_{F}$ - pojemność filtru, $U_{A C}$ - źródło napięcia przemiennego, $U_{D C}$ - źródło napięcia stałego, $L_{L}$ - indukcyjność obciążenia, $\mathrm{R}_{\mathrm{L}}$ - rezystancja obciążenia 
- w modelu przyjęto zasilanie idealnym źródłem napięcia stałego $\mathrm{U}_{\mathrm{DC}}$, $\mathrm{z}$ nałożona składową przemienną $\mathrm{U}_{\mathrm{AC}}$,

- głębokość modulacji napięcia wyjściowego falownika $\mathrm{z}$ opcją PWM zmieniano proporcjonalnie do zmiany częstotliwości fali nośnej,

- częstotliwość modulacji miała stałą wartość dla każdej serii symulacji

W trakcie ustalania parametrów symulacji należy zwrócić uwagę, aby wyniki wyznaczania impedancji układu nie były zakłócane harmonicznymi generowanymi przez falownik. W tym celu tak dobierano częstotliwość fali nośnej falownika w poszczególnych stanach, aby generowane widmo harmonicznych prądu nie pokrywało się z częstotliwościami, dla których wyznaczana była impedancja wejściowa.

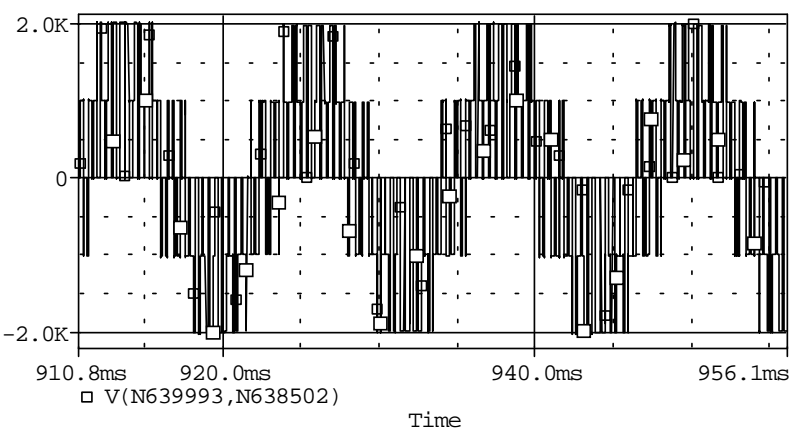

Rys. 2 Przebieg napięcia fazowego obciążenia MODEL 2

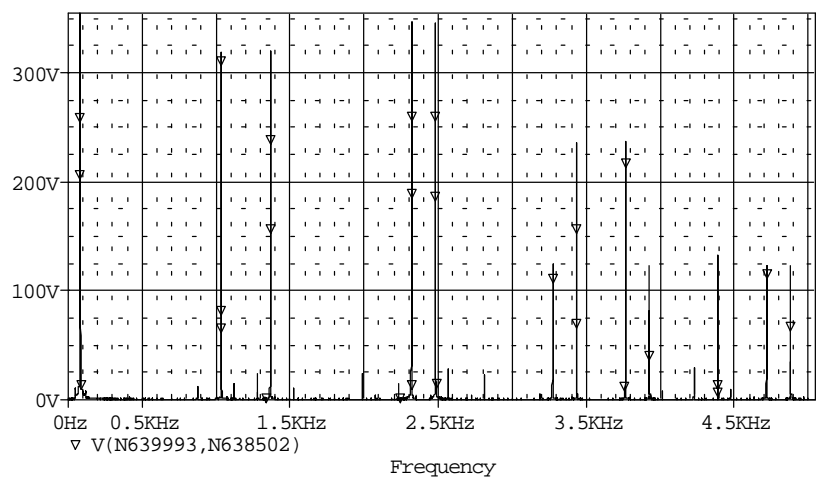

Rys. 3 Widmo napięcia fazowego obciążenia MODEL 2

\section{Impedancja wejściowa falownika napięcia}

Analizę impedancji wejściowej opisanego wyżej układu rozpoczęto od serii symulacji komputerowych dla modelu falownika bez modulacji napięcia wyjściowego PWM. Symulacje te miały na celu wyznaczenie impedancji wejściowej falownikowego układu napędowego w funkcji częstotliwości pracy przekształtnika dla różnych wartości parametrów układu. Działania te pozwoliły na określenie wpływu poszczególnych parametrów układu napędowego na zmienność impedancji wejściowej w funkcji punktu pracy przetwornicy oraz wpływu wartości poszczególnych parametrów na charakterystykę Zin = $f\left(f_{\text {fal }}\right)$.

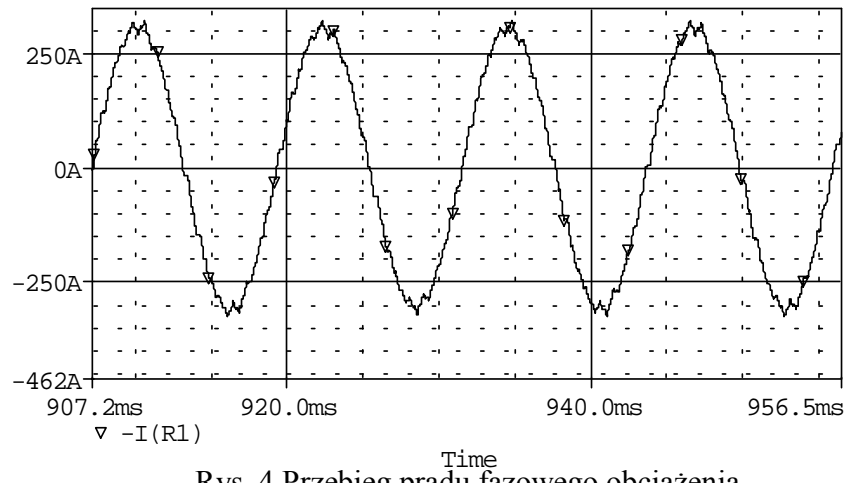

Rys. 4 Przebieg prądu fazowego obciążenia MODEL 2

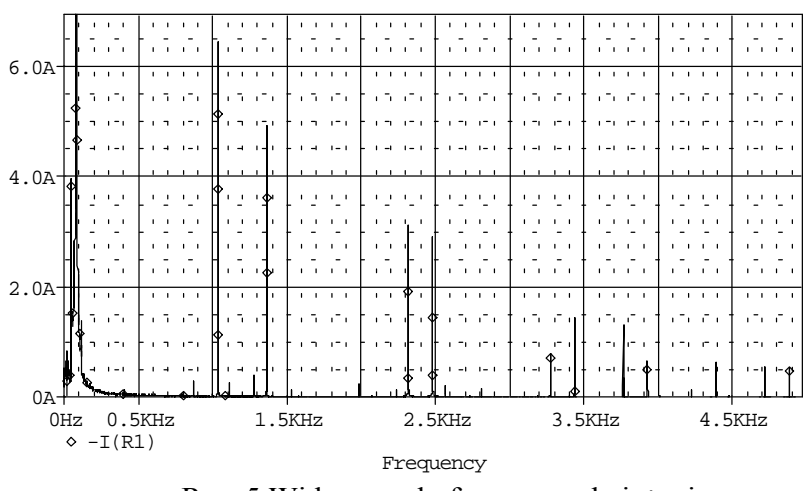

Rys. 5 Widmo prądu fazowego obciążenia MODEL 2

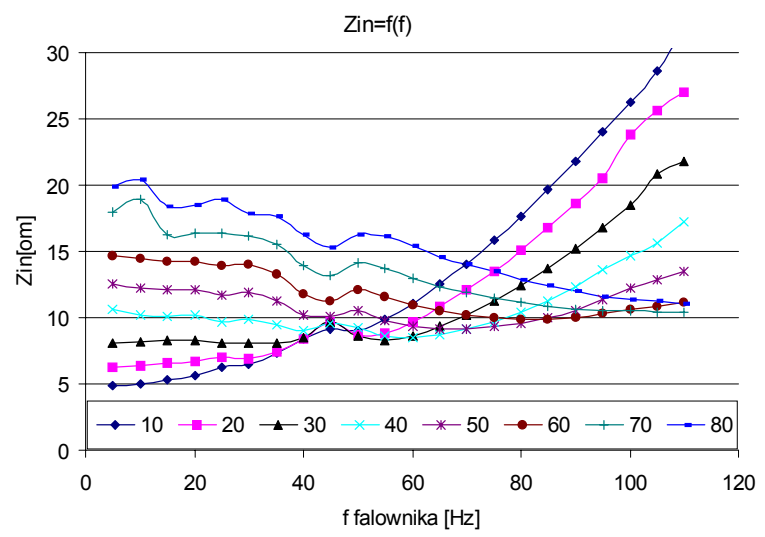

Rys. 6 Impedancja wejściowa układu dla wybranych częstotliwości

$\mathrm{Na}$ rysunku 6 przedstawiono wyniki wyznaczania impedancji wejściowej metodą symulacji komputerowej dla modelu 1 dla wybranych częstotliwości. Widać, że w zależności od rozpatrywanej częstotliwości impedancja ta może rosnąc lub maleć wraz ze zwiększaniem częstotliwości fali nośnej przetwornicy. Na rysunku 7 przedstawiono wpływ rezystancji obciążenia $\left(R_{L}\right)$ na charakterystykę Zin $=f\left(f_{\text {fal }}\right)\left(f_{\text {fal }}\right.$ - częstotliwość fali nośnej falownika). Przy tak dobranych parametrach układu, zwiększenie rezystancji obciążenia powoduje zmniejszenie zmienności impedancji wejściowej układu. Zwiększenie indukcyjności obciążenia (rysunek 8) powoduje pogłębienie zmienności impedancji i podwyższenie jej poziomu. na rysunkach od 9 do 12 przedstawiono wpływ parametrów filtru wejściowego. Najmniejszy wpływ na charakterystykę Zin ma rezystancją filtru wejściowego. Zwiększenie 
zarówno indukcyjności jak i pojemności filtru powoduje podwyższenie wartości impedancji układu i obniżenie jej zmienności. Najprostszym sposobem na stabilizacje charakterystyki Zin $=f(f)$ jest zwiększenie pojemności filtru wejściowego $\left(\mathrm{C}_{\mathrm{F}}\right)$.

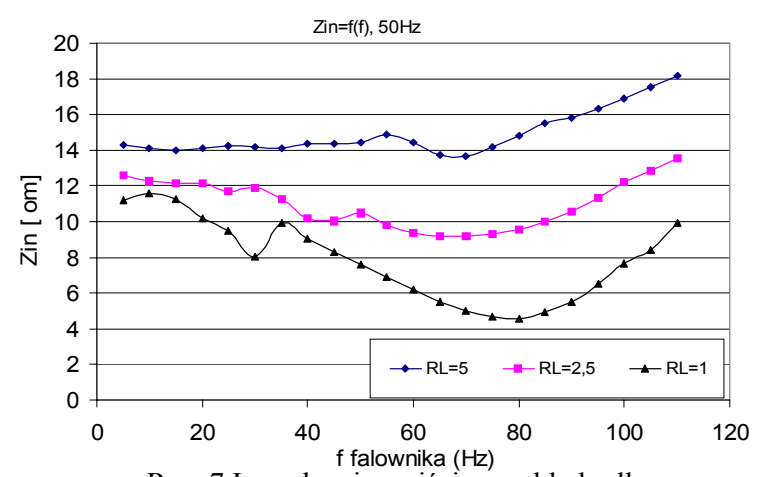

Rys. 7 Impedancja wejściowa układu dla częstotliwości $50 \mathrm{~Hz}$, dla różnych wartości rezystancji obciążenia

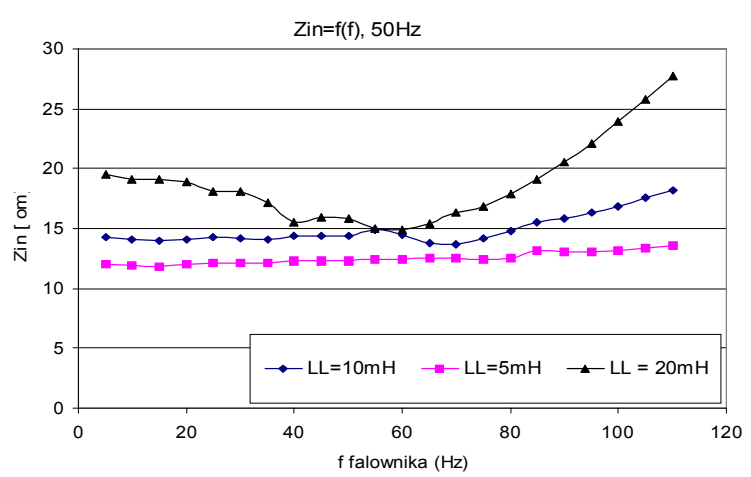

Rys. 8 Impedancja wejściowa układu dla częstotliwości $50 \mathrm{~Hz}$, dla różnych wartości indukcyjności obciążenia

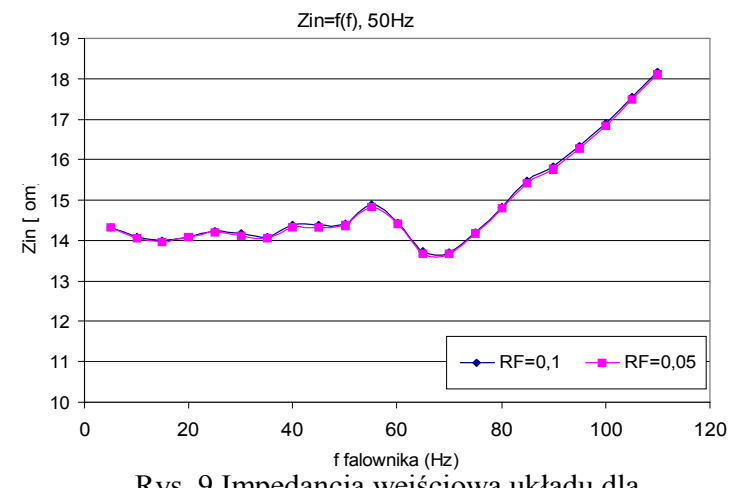

Rys. 9 Impedancja wejściowa układu dla częstotliwości $50 \mathrm{~Hz}$, dla różnych wartości rezystancji filtra wejściowego

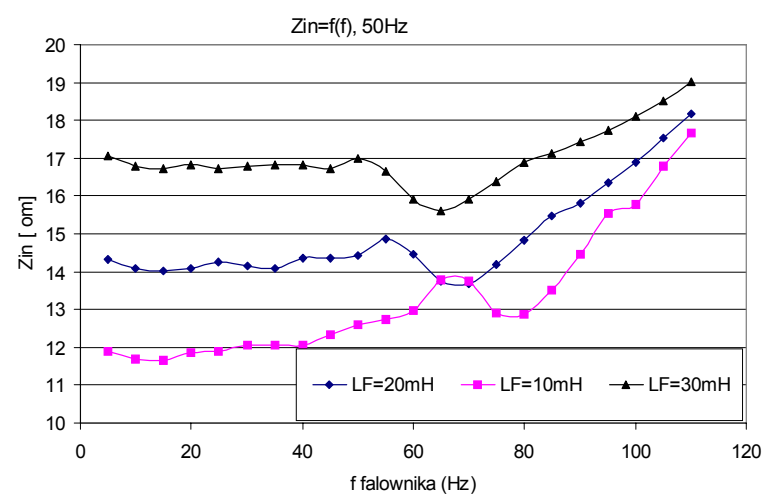

Rys. 10 Impedancja wejściowa układu dla częstotliwości $50 \mathrm{~Hz}$, dla różnych wartości indukcyjności filtra wejściowego

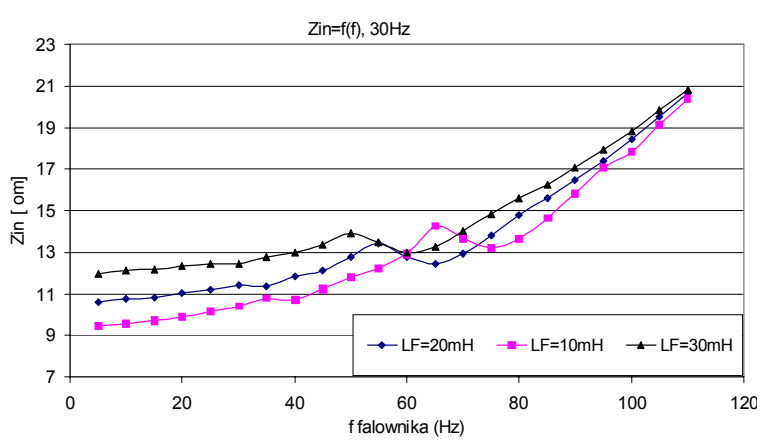

Rys. 11 Impedancja wejściowa układu dla czestotliwości $30 \mathrm{~Hz}$, dla różnych wartości indukcyjności filtra wejściowego

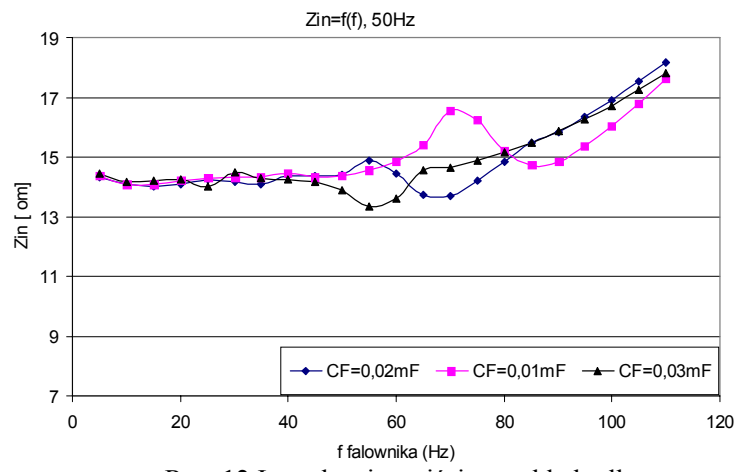

Rys. 12 Impedancja wejściowa układu dla częstotliwości $50 \mathrm{~Hz}$, dla różnych wartości pojemności filtra wejściowego

\section{Impedancja wejściowa falownika napięcia $\mathrm{z}$ mo- dulacją PWM}

Kolejna seria symulacji została przeprowadzona na modelu układu napędowego umożliwiającym uwzględnienie modulacji napięcia wyjściowego PWM. Porównując rysunek 13 z rysunkiem 6 widać wyraźny wpływ wprowadzenia modulacji PWM na impedancje układu. Przeprowadzono również symulacje dla stałej częstotliwości fali nośnej zmieniając tylko głębokość modulacji (rys. 14) jak również dla stałej głębokości modulacji przy zmiennej częstotliwości falownika (rys. 15). Wyniki symulacji świadczą o dominującym wpływie głębokości modulacji PWM na ksztalt charakterystyki impedancji wejściowej układu. Porównano również impedancję wejściowa układu pracującego ze stała częstotliwością fali nośnej (zmienna tylko głębokość modulacji) z impedancją układu, w którym głębokość modulacji jest płynnie zmieniana wraz z częstotliwością fali nośnej (rys 16). 


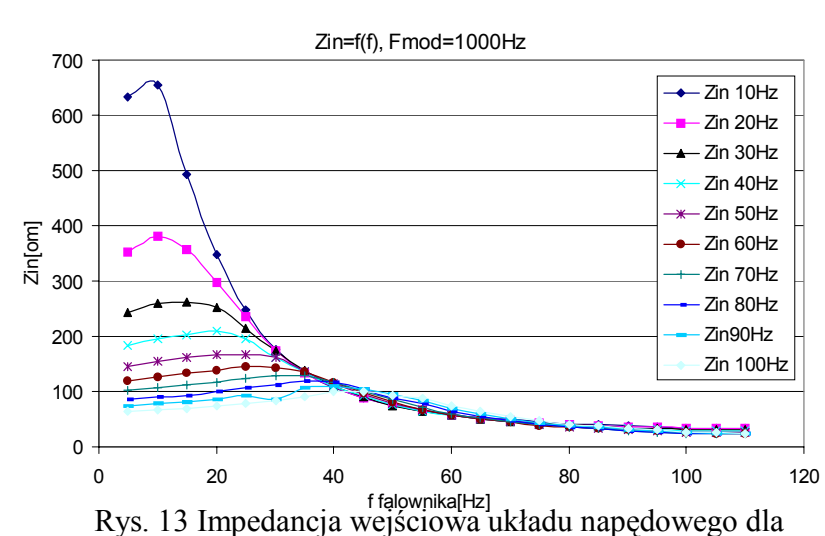

wybranych częstotliwości przy stałej częstotliwości modulacji $1000 \mathrm{~Hz}$

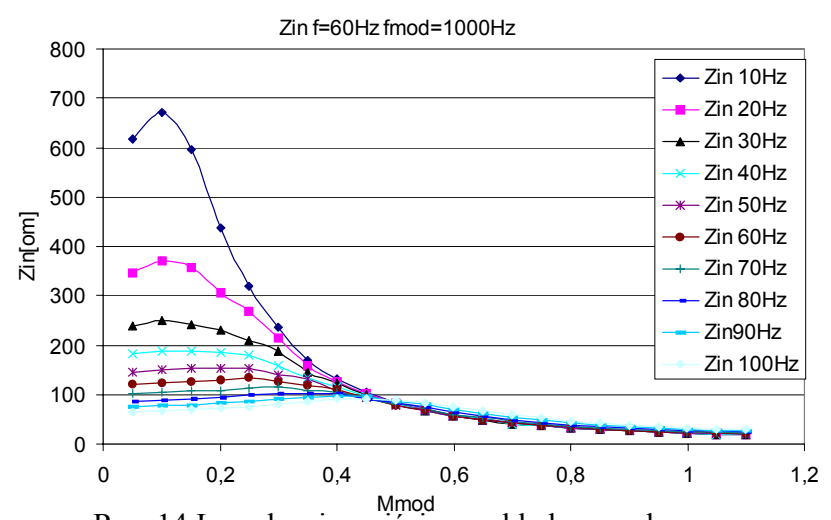

Rys. 14 Impedancja wejściowa układu napędowego w funkcji głębokości modulacji, dla wybranych częstotliwości, przy stałej częstotliwości falownika

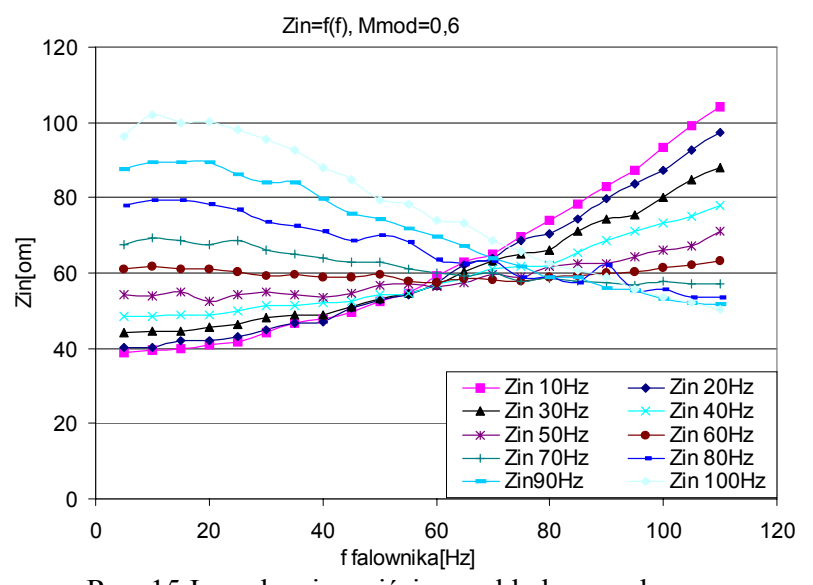

Rys. 15 Impedancja wejściowa układu napędowego w funkcji częstotliwości falownika, dla wybranych częstotliwości, przy stałej głębokości modulacji $\operatorname{Mmod}=0,6$

Na rysunkach 17 i 18 przedstawiono wpływ zmiany parametrów filtru wejściowego na impedancję układu W tym przypadku parametrem decydującym o kształcie charakterystyki impedancji wejściowej jest pojemność filtru wejściowego.

Dodatkowo wykonano analizę wpływu parametrów obciążenia (rys. 19, 20, 20,21) jak również wpływu częstotliwości modulacji PWM na impedancje omawianego układu

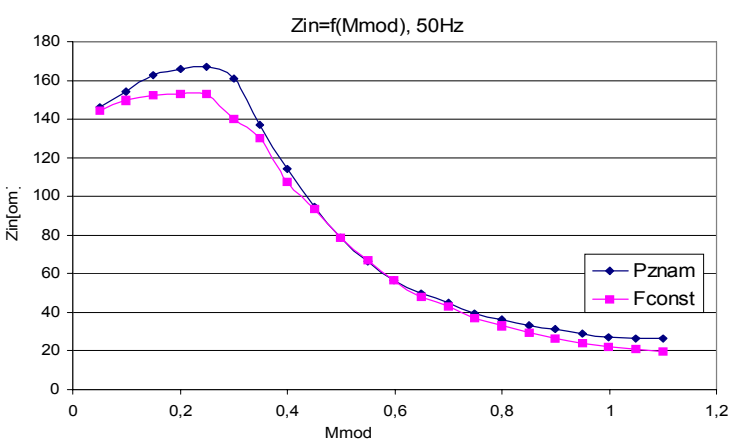

Rys. 16 Impedancja wejściowa układu napędowego w funkcji głębokości modulacji, dla częstotliwości $50 \mathrm{~Hz}$ gdzie: Pznam - częstotliwość falownika zmienna płynnie z głębokością modulacji, Fconst - częstotliwość falownika stała

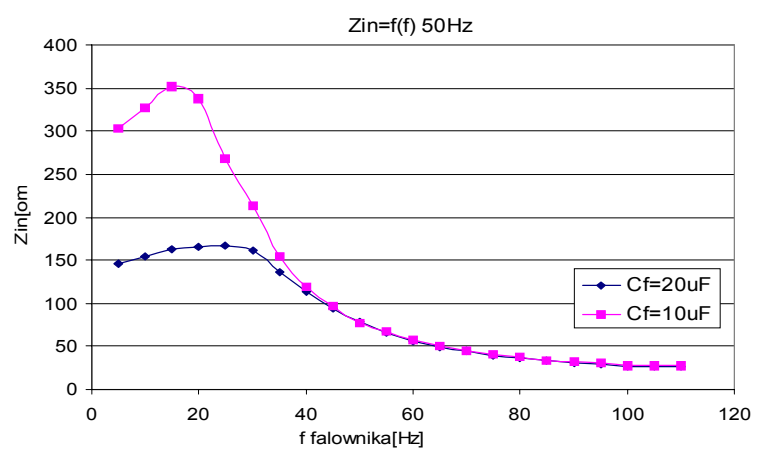

Rys. 17 Impedancja wejściowa układu napędowego w funkcji częstotliwości falownika, dla częstotliwości50 Hz przy dwóch pojemnościach filtru wejściowego

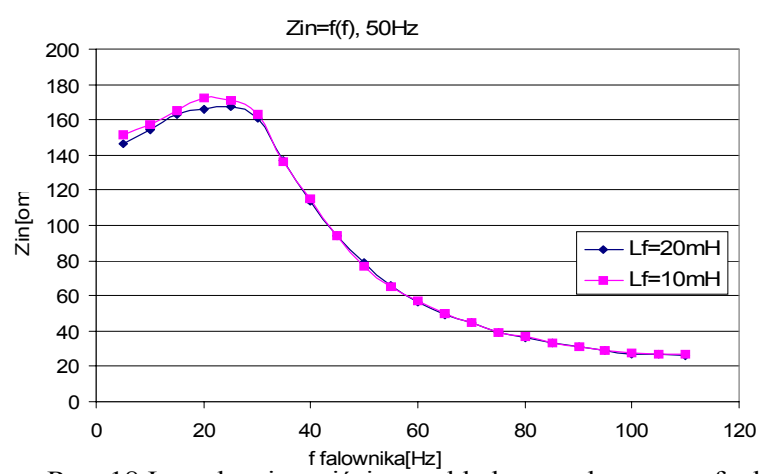

Rys. 18 Impedancja wejściowa układu napędowego w funkcji częstotliwości falownika, dla częstotliwości50Hz przy dwóch indukcyjnościach filtru wejściowego

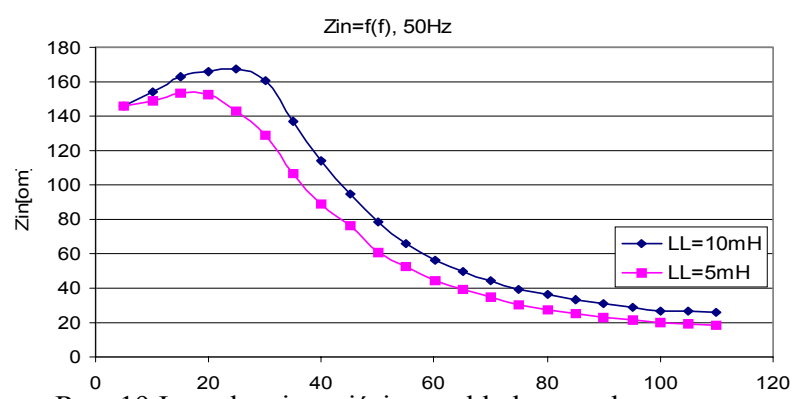

Rys. 19 Impedancja układu napędowego w

funkcji częstotliwości falownika, dla częstotliwości $50 \mathrm{~Hz}$ przy dwóch indukcyjnościach obciążenia 


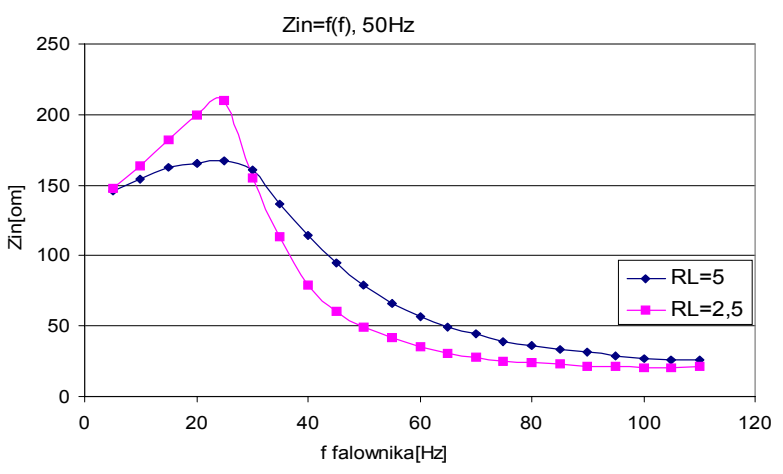

Rys. 20 Impedancja wejściowa układu napędowego w funkcji częstotliwości falownika, dla częstotliwości $50 \mathrm{~Hz}$ przy dwóch rezystancjach obciążenia

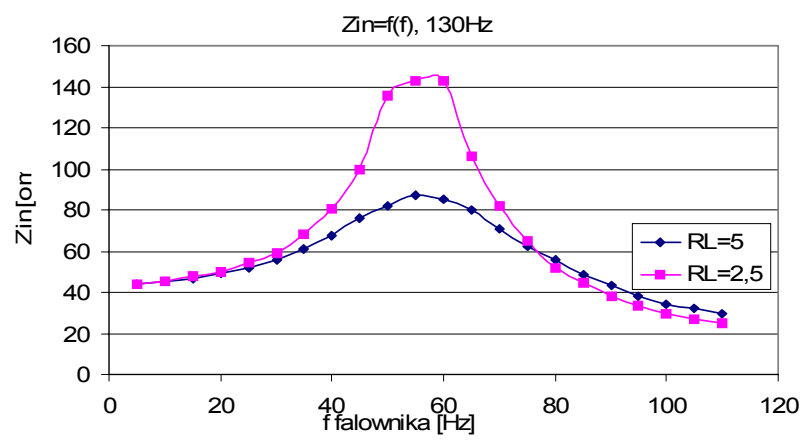

Rys. 21 Impedancja wejściowa układu napędowego w funkcji częstotliwości falownika, dla częstotliwości 130 Hz przy dwóch rezystancjach obciążenia

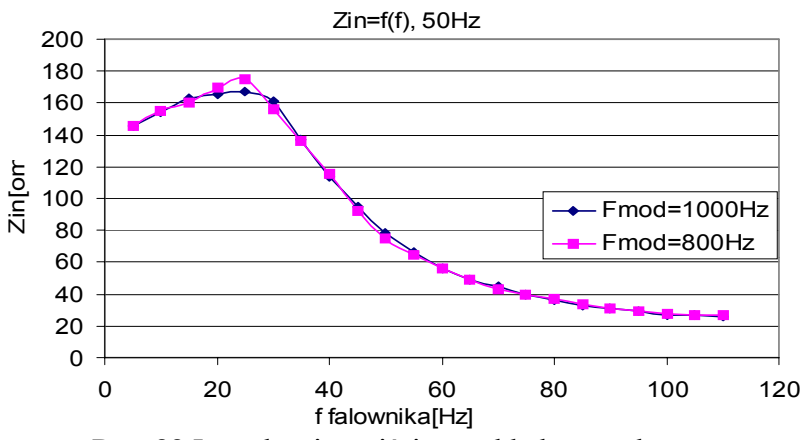

Rys. 22 Impedancja wejściowa układu napędowego w funkcji częstotliwości falownika, dla częstotliwości $50 \mathrm{~Hz}$ przy dwóch częstotliwościach modulacji

\section{Podsumowanie}

$\mathrm{W}$ artykule przedstawiono wyniki badań dotyczących wyznaczania impedancji falownikowego układu napędowego metodą symulacji komputerowej. Głównym celem pracy była analiza wpływu poszczególnych parametrów układu napędowego na charakterystykę impedancji wejściowej pojazdu w funkcji punktu pracy przetwornicy Zin $=\mathrm{f}(\mathrm{f})$. Przeprowadzono analizę dla dwóch przypadków. W pierwszym przypadku analizie poddano falownik bez modulacji napięcia wyjściowego (MODEL 1). W tym przypadku za stały punkt pracy falownika uważano wybraną częstotliwość fali nośnej. W drugim przypadku model umożliwiał wprowadzenie modulacji PWM (MODEL2). W tym przypadku punkt pracy przetwornicy ustalany był przez podanie częstotliwości fali nośnej, częstotliwości modulacji oraz głębokości modulacji. $\mathrm{Na}$ drodze badań symulacyjnych wykazano, że para- metrem decydującym o stałości impedancji wejściowej w funkcji punktu pracy przetwornicy w pojazdach trakcyjnych wyposażonych $\mathrm{w}$ falowniki jest odpowiednia wartość pojemność filtru wejściowego $\left(\mathrm{C}_{\mathrm{F}}\right)$. Duża pojemność $\mathrm{C}_{\mathrm{F}}$ pozwala na skuteczne odseparowanie obwodu pośredniczącego prądu stałego wraz z falownikiem od układu zasilania. Wyniki symulacji przedstawione $\mathrm{w}$ artykule uzyskano przy obniżonej pojemności filtru wejściowego, co pozwoliło na obserwację wpływu przetwornicy na charakterystykę Zin $=\mathrm{f}(\mathrm{f})$. Wykazano również, iż pojemność filtru wejściowego jest parametrem decydującym również o kształcie charakterystyki impedancji wejściowej rozpatrywanych układów. Ponadto pokazano, że częstotliwość modulacji nie ma znaczącego wpływu na rozpatrywaną charakterystykę. Należy również zwrócić uwagę na wpływ zastosowania modulacji PWM, która diametralnie zmienia badana charakterystykę, gdyż układy napędowe z obniżoną pojemnością filtru wejściowego charakteryzują się zmiennością impedancji wejściowej w funkcji częstotliwości pracy falownika i głębokości modulacji napięcia wyjściowego przetwornicy.

W artykule wykorzystano wyniki prac wykonanych w ramach projektu badawczego promotorskiego N N510 355036 finansowanego przez Ministerstwo Nauki i Szkolnictwa Wyższego.

\section{Bibliografia}

[1] Białoń A. - "Opracowanie dopuszczalnych parametrów zakłóceń dla urzqdzeń srk, taczności $i$ pojazdów trakcyjnych". Temat CNTK 6915/23 1999,

[2] Le Roux W., Steyn B.M - "Simulation studies of $50 \mathrm{~Hz}$ locomotive impedance and DC substation interference sources". - Computers in Railways IX., WIT Press, 2004

[3] Mellitt B., Taufiq J.A., Xiaoping J.: "Input impedance of chopper equipment and its significance in low-frequency track circuits". IEE PROC., Vol.136, Pt. B, No. 1, JANUARY 1989,

[4] Papers presented at IRSE International Forum Traction/Signalling Compatibility. April 24,1997 London

[5] Skarpetowski G., Zajac W. - Symulacja odcinka linii kolejowej o złożonym obciqżeniu konwencjonalnoprzeksztaltnikowym. MET2007

[6] Szelag A. - "Zagadnienia wpływu parametrów i rozwiazań elementów obwodów podstacja-sieć trakcyjna-pojazd na problemy kompatybilności $w$ systemie trakcji elektrycznej". MET'2007, Warszawa

[7] Szelag A.: "Zagadnienia analizy i projektowania systemu trakcji elektrycznej pradu statego z zastosowaniem technik modelowania $i$ symulacji". Oficyna Wydawnicza Politechniki Warszawskiej, Warszawa 2002

[8] Szelag A., Steczek M. - "Symulacyjna metoda analizy wplywu typu filtru pojazdu z napędem impulsowym i filtrów podstacji na harmoniczne pradu". MET'2007

[9] Szelag A., Steczek M. - 3 kV DC system: converter-driven vehicle - signalling circuit compatibility. Criteria and analysis. Electromotion 17 (2010), 70-78

[10] Zajac W., Szelag A.,: "Harmonic distortion caused by suburban and underground rolling stock with D.C. motors". CIEP 96, Cuernavaca, Mexico October 14-17,

[11] Zajac W.(kier.): "Stosowanie tyrystorów w trakcji elektrycznej. Środki przeciwzakłóceniowe". Sprawozdanie z prac tematu 0.5.09. СРВP 02.19., 1986 - 1990. 